\title{
PREVALENCE AND MOLECULAR TYPING OF METHICILLIN-RESISTANT STAPHYLOCOCCUS AUREUS CARRYING PANTON-VALENTINE LEUKOCIDIN GENE
}

\author{
MARYAM RAHIMPOUR HeSARI ${ }^{1}$, Ali SAlEHZADEH ${ }^{1 *}$ and REZA KAZEMI \\ DARSANAKI $^{2}$ \\ ${ }^{1}$ Department of Biology, Rasht Branch, Islamic Azad University, Rasht, Iran \\ ${ }^{2}$ Young Researchers and Elites Club, Lahijan Branch, Islamic Azad University, Lahijan, \\ Iran
}

(Received: 18 November 2016; accepted: 26 May 2017)

Panton-Valentine leukocidin $(p v l)$ toxin is an important virulence factor of Staphylococcus aureus. The main genes are coa and spa for distinguishing and typing of $S$. aureus isolates. The aim of this study was to investigate antibiotic resistance, presence of $m e c \mathrm{~A}$ and $p v l$ genes, as well as epidemiological typing of these isolates according to polymerase chain reaction-restriction fragment length polymorphism (PCR-RFLP) method in clinical sample isolated from Rasht city, Iran. A total of 250 clinical samples have been isolated from different hospitals. First, isolates of $S$. aureus were identified through microbiological methods and their antibiotic sensitivity was determined by disk diffusion agar based on a standard method of Clinical and Laboratory Standards Institute. DNA was extracted by boiling and presence of $p v l$ and mecA genes was investigated by PCR using specific primers. To type these isolates, amplification of fragments of coa and spa genes was done and restriction enzyme digestion pattern was determined by PCR-RFLP method. Among the 250 samples, 50 isolates belonged to $S$. aureus and results of antibiotic sensitivity showed that $68 \%$ (34 samples) of isolates were methicillin resistant. Frequency of mecA and $p v l$ genes among $S$. aureus isolates were $60 \%$ (30 samples) and $20 \%$ (10 samples). The PCR of coa gene showed three patterns whereas that of spa gene showed two patterns for enzyme digestion. Result of PCR-RFLP using HaeIII enzymes for coa gene and Bsp1431 for spa gene showed three patterns for enzyme digestion. Recent studies indicated increase in the resistance of $S$. aureus to different antibiotics, which is a serious problem in the treatment of infections resulting from $S$. aureus in this region. The result of PCR of $p v l$ showed high frequency of this gene in this region, and coa and spa typing by PCR-RFLP was a useful tool for typing of $S$. aureus isolates.

Keywords: Staphylococcus aureus, mecA, pvl, coa, spa, PCR-RFLP

*Corresponding author; E-mails: salehzadehmb@yahoo.com, salehzadeh@iaurasht.ac.ir 


\section{Introduction}

Staphylococcus aureus is a Gram-positive, facultative anaerobic bacterium, and is a common pathogen in hospital cases. Studies show that it can exist in $20 \%$ of people constantly, while $60 \%$ of people are considered as alternative carriers of this bacterium. This bacterium causes an extensive spectrum of diseases, such as endocarditis, osteomyelitis, pneumonia, toxic shock syndrome, boils or abscesses, and the most important way of delivery, this bacterium is caused through polluted hands, specifically in health-care centers [1]. The resistance of $S$. aureus to antibiotic has special importance, because this bacterium shows drug resistance as compared with other bacteria. Based on geographical region, it has faced significant changes in the pattern of antibiotic sensitivity in previous years. One main problem in the treatment and prevention of infections by $S$. aureus is the resistance of this bacterium to different antibiotics namely, $\beta$-lactams, aminoglycosides, and macrolides. Infections caused by multiresistant $S$. aureus leads to higher mortality, longer hospital stay, increased cost of treatment, and possible further dissemination of resistant strains [2]. Studies showed that about $30 \%$ to more than $50 \%$ of $S$. aureus isolates are resistant to methicillin and the reason is related to the presence of mecA gene [3]. The pathogenicity of S. aureus infections is related to various compounds of bacteria level and extracellular protein, such as Panton-Valentine leukocidin $(p v l)$ [4]. $p v l$ is one of the important virulence factors in $S$. aureus and is composed of two protein components $\mathrm{S}(38 \mathrm{KDa})$ and F (32 KDa), which are controlled by the Luks/pv and Lukf/pv genes. The product of this gene can cause opening of calcium channels, necrosis, and apoptosis of human leukocytes [5-7]. Positive $p v l$ strains of $S$. aureus have high virulence and are more accompanied by furuncle, skin abscesses, and infections with severe necrosis [8]. Molecular typing of $S$. aureus is a useful tool to discriminate isolates during tracing source of infection and to strengthen infection control. It is important to note that a variety of Staphylococcus coagulase enzyme causes difference in their antigenicity. Coa gene is the main gene that discriminates isolates of $S$. aureus. The end of 3' repetitive short frequency with the size of $81 \mathrm{bp}$ and their number is different among different strains. Coa gene was observed in all the Staphylococcus strains that shows capability of typing for this gene [9]. Protein A is the surface protein and coded by spa gene, a region which in a repetitive district, is identified at the end of $3^{\prime} \mathrm{X}$ region. Repeating region of district $\mathrm{X}$ includes 12 sections with length of 24 nucleotides and these 24 nucleotides are a polymorphism region with repetitive and short frequency, and variation of protein $\mathrm{A}$ is due to variation in $\mathrm{X}$ region [10]. Some types of $S$. aureus isolates do not have the ability to retain protein A in their wall, so they release all the proteins produced. This phenomenon 
is mainly observed in all methicillin-resistant $S$. aureus (MRSA) [11]. Regarding the importance of these strains, the aim of this research was to study antibiotic resistance and consider the presence of mecA gene for confirming MRSA strains and also consider the rate of distribution of $p v l$ gene among clinical strains of $S$. aureus isolated from hospitals of Rasht, Iran and molecular typing of these isolates based on coa and spa genes through polymerase chain reaction-restriction fragment length polymorphism (PCR-RFLP) method.

\section{Materials and Methods}

\section{Bacterial isolates}

In this study which lasted over a year and was approved by the committee of research ethics, written informed consent of patients, 250 clinical samples (injury, skin, blood, and urine) from different hospitals (Razi, Poursina, Ghaem, Alzahra, and Ashtiani's lab) were collected during 2014-2015. Phenotypic identification of strains of $S$. aureus was carried out by test of Gram-staining, catalase, coagulase, DNase, and cultivation on the environment of Baird-Parker agar and Mannitol Salt agar (Merck, Germany) [12].

\section{Antibiotic susceptibility}

Microbial sensitivity test was carried out using Kirby-Bauer method and according to the instruction of the Clinical and Laboratory Standards Institute [13]. Sensitivity of isolates of $S$. aureus against antibiotic discs of cefoxitin $(10 \mu \mathrm{g})$, neomycin $(10 \mu \mathrm{g})$, ciprofloxacin $(5 \mu \mathrm{g})$, penicillin (10 units), gentamicin $(10 \mu \mathrm{g})$, amoxicillin $(10 \mu \mathrm{g})$, chloramphenicol $(30 \mu \mathrm{g})$, and clindamycin $(2 \mu \mathrm{g})$ (MAST, UK) was done in Mueller-Hinton agar (Merck, Germany). In all experiments, standard strain of S. aureus (ATCC 33591) was used as positive control resistant against methicillin (having mecA gene) and standard strain of S. aureus (ATCC 49775) as positive control having $p v l$ gene and S. epidermidis (ATCC 12228) was used as negative control.

\section{DNA extraction and PCR}

DNA extraction carried out using DNA Extraction Kit (CinnaGen, Tehran, Iran) and consequently PCR method was done. PCR was consistently performed 
Table I. Sequence of primers used in PCR [14-17]

\begin{tabular}{ll}
\hline Gene & \multicolumn{1}{c}{ Primer sequence $\left(5^{\prime}-3^{\prime}\right)$} \\
\hline mecA-F & TCCAGATTACAACTTCACCAGG \\
mecA-R & CCACTTCATATCTTGTAACG \\
pvl-F & AGAAGATACAAGTAGCGATAAGTG \\
pvl-R & AAGGATTGAAACCACTGTGTAC \\
coa-F & CGAGACCAAGATTCAACAAG \\
coa-R & AAAGAAAACCACTCACATCA \\
spa-F & ATCTGGTGGCGTAACACCTG \\
spa-R & CGCTGCACCTAACGCTAATG \\
\hline
\end{tabular}

in a $20 \mu \mathrm{L}$ reaction volume, with each reaction mixture containing $1.0 \mu \mathrm{L}$ of DNA template, $10 \mathrm{mM}$ of each primer, $2.0 \mu \mathrm{L}$ of Taq buffer, $2.5 \mathrm{mM}$ of deoxynucleotide triphosphates, and $2.5 \mathrm{mM}$ of Taq polymerase (CinnaGen, Tehran, Iran). Sequence of primers used in PCR is shown in Table I.

Thermal cycling was performed in a Prime Thermal Cycler (Techne, Germany) under the following conditions: denaturation for $5 \mathrm{~min}$ at $94{ }^{\circ} \mathrm{C}$, 1-min amplification cycles at $94{ }^{\circ} \mathrm{C}$, and additional amplification cycles for $50 \mathrm{~s}$ at $55^{\circ} \mathrm{C}, 1 \mathrm{~min}$ at $72{ }^{\circ} \mathrm{C}$, and a final extension cycle for $10 \mathrm{~min}$ at $72{ }^{\circ} \mathrm{C}$. The PCR products were detected by electrophoresis on agarose gels, stained with power load stain, and photographed using a UV transillumination imaging system.

\section{RFLP of coa gene PCR products}

Depending on 81 bp repeats, a strain analysis of PCR-RFLP products was performed with HaeIII restriction enzyme (Thermo Scientific, USA), where $10 \mu \mathrm{L}$ of PCR product of coa gene was incubated with $6 \mathrm{U}$ of the enzyme at $37{ }^{\circ} \mathrm{C}$ for $45 \mathrm{~min}$ in a water bath.

\section{RFLP of spa gene PCR products}

Five $\mu \mathrm{L}$ of each spa gene amplicon and 10 units of $B s p 1431$ restriction enzyme (Thermo Scientific, USA) were incubated at $37{ }^{\circ} \mathrm{C}$ for $3 \mathrm{~h}$. The PCR products and restriction digest fragments were detected by electrophoresis in $2 \%$ agarose gel. The interpretation criteria for identifying different strains were a single band difference. Unique PCR-RFLP patterns were assigned a genotype. It should be noted that in this step of studying, strain of standard $S$. aureus ATCC $8325 / 4$ was used as control. Statistical analysis was carried out through statistical software of SPSS 22 and $\chi^{2}$ test. 


\section{Results}

Samples were separated from urine, blood, skin, and wound and using Gram stain, mannitol salt agar, catalase test, coagulase test, 50 isolates of $S$. aureus were separated (Table II).

The sensitivity of $S$. aureus isolates to the tested antibiotics is shown in Table III. A percentage of 68 were resistant to antibiotic cefoxitin and was considered as MRSA strains. The highest resistance related to antibiotics of penicillin (98\%), ampicillin (90\%), amoxicillin and trimethoprim (86\%) and the least resistance related to antibiotics of vancomycin (sensitive 100\%) and ciprofloxacin (sensitive 56\%). Total resistance rate of antibiotic in strains separated from urine and wound samples was more than other strains. Resistance to vancomycin was not observed in any strain.

Table II. Distribution of $S$. aureus according to the type of samples and gender

\begin{tabular}{|c|c|c|c|c|c|c|}
\hline \multirow[b]{2}{*}{ Type of samples } & \multicolumn{2}{|c|}{ Female } & \multicolumn{2}{|c|}{ Male } & \multicolumn{2}{|c|}{ Total } \\
\hline & $\%$ & $N$ & $\%$ & $N$ & $\%$ & $N$ \\
\hline Blood & 6 & 15 & 8 & 20 & 14 & 35 \\
\hline Trauma & 12.8 & 32 & 4 & 10 & 16.8 & 42 \\
\hline Skin & 11.2 & 28 & 6 & 15 & 17.2 & 43 \\
\hline Urine & 50 & 60 & 28 & 70 & 52 & 130 \\
\hline
\end{tabular}

Table III. Antibiotic susceptibility patterns for S. aureus

\begin{tabular}{|c|c|c|c|c|c|c|}
\hline \multirow[b]{2}{*}{ Antibiotics } & \multicolumn{2}{|c|}{ Resistant } & \multicolumn{2}{|c|}{ Intermediate } & \multicolumn{2}{|c|}{ Sensitive } \\
\hline & $\%$ & $N$ & $\%$ & $N$ & $\%$ & $N$ \\
\hline Cefoxitin & 68 & 34 & 0 & 0 & 32 & 16 \\
\hline Vancomycin & 0 & 0 & 0 & 0 & 100 & 50 \\
\hline Ciprofloxacin & 42 & 21 & 2 & 1 & 56 & 28 \\
\hline Penicillin & 98 & 49 & 0 & 0 & 2 & 1 \\
\hline Erythromycin & 56 & 28 & 18 & 9 & 26 & 13 \\
\hline Trimethoprim & 86 & 43 & 6 & 3 & 8 & 4 \\
\hline Amikacin & 42 & 21 & 6 & 3 & 52 & 26 \\
\hline Ampicillin & 90 & 45 & 0 & 0 & 10 & 5 \\
\hline Gentamicin & 40 & 20 & 6 & 3 & 54 & 27 \\
\hline Amoxicillin & 86 & 43 & 0 & 0 & 14 & 7 \\
\hline Chloramphenicol & 8 & 4 & 14 & 7 & 78 & 39 \\
\hline Clindamycin & 46 & 23 & 12 & 6 & 42 & 21 \\
\hline
\end{tabular}




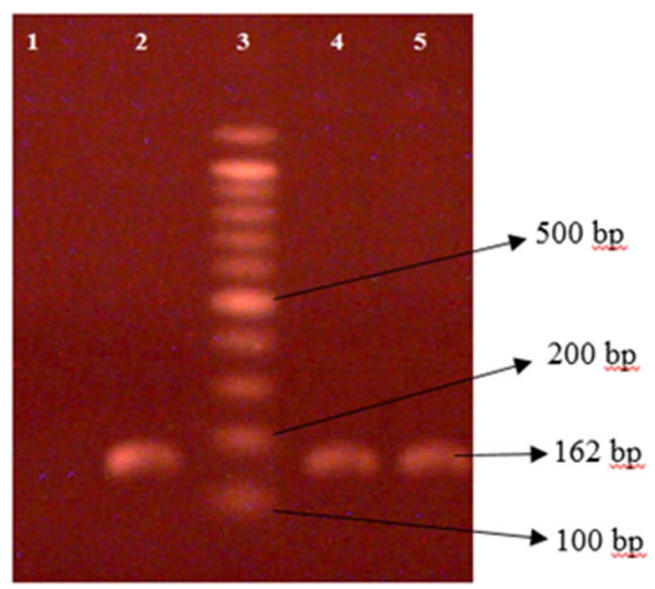

Figure 1. 1\% agarose gel electrophoresis analysis of PCR amplification products of mecA gene of 162 bp extracted from $S$. aureus. Lane 1: negative control (no DNA template); lanes 2, 4: positive isolates; lane 3: DNA molecular size marker (100 bp ladder); lane 5: positive control (mecA-positive strain ATCC 33591)

\section{Amplification of mecA gene}

The results showed that the distribution of mecA gene existed in staphylococcus in $60 \%$ of samples (30 samples). It should be noted that the rate of distribution of mecA gene in samples of $S$. aureus separated from wound samples was more than other samples; from 30 samples, 15 samples belonged to wound samples $(p<0.032)$ (Figure 1).

\section{Amplification of pvl gene}

For considering existence of $p v l$ gene in strains of separated $S$. aureus, specific primers of this gene were used and we expected existence of the band $575 \mathrm{bp}$ that its image was observed in electrophorese gel. $p v l$ gene was positive in $20 \%$ of samples (10 samples) (Figure 2). It is necessary to mention that there was not meaningful relationship between existence of $p v l$ gene, type of sample $(p<0.046)$, and mecA gene among strains $(p<0.015)$.

\section{Amplification of coa and spa genes}

For considering existence of coa gene and spa gene in strains of separated $S$. aureus, specific primers of these genes were used and we expected existence of $575 \mathrm{bp}$ band for both genes. The result showed that each has two patterns of 


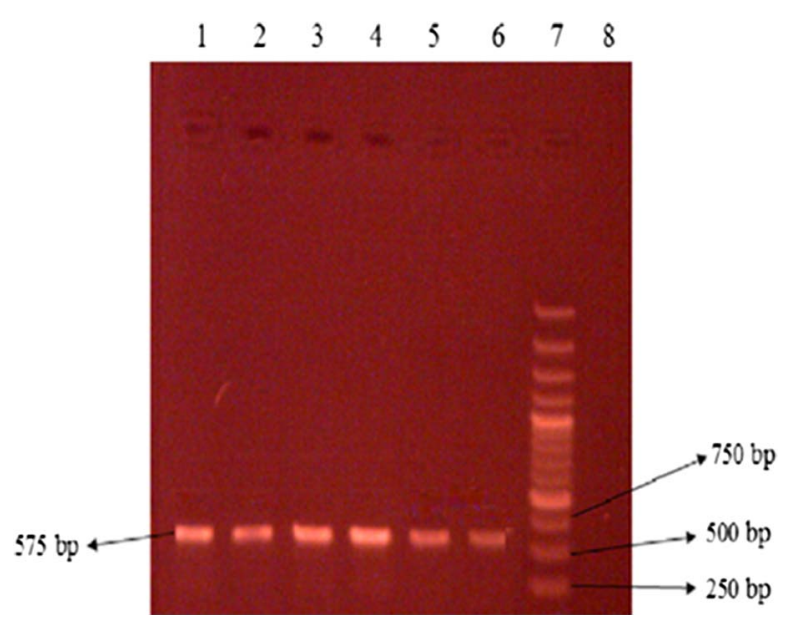

Figure 2. 1\% agarose gel electrophoresis analysis of PCR of $p v l$ gene. Lanes 1-5: positive isolates; lane 6: positive control ( $p v l$-positive strain ATCC 49775); lane 7: DNA molecular size marker (100 bp ladder); lane 8: negative control

amplification and size of product PCR of genes was varied. PCR products of coa gene were $891 \mathrm{bp}$ in some isolates, 810 and $405 \mathrm{bp}$ in others. PCR products of spa gene were 1,200 bp in some isolates, 1,296 and $240 \mathrm{bp}$ in others (Figures 3 and 4).

\section{PCR-RFLP of coa and spa genes}

For being certain about different genetic content of PCR bands, RFLP technique was used. Regarding research in computer (in silico) on coa and spa

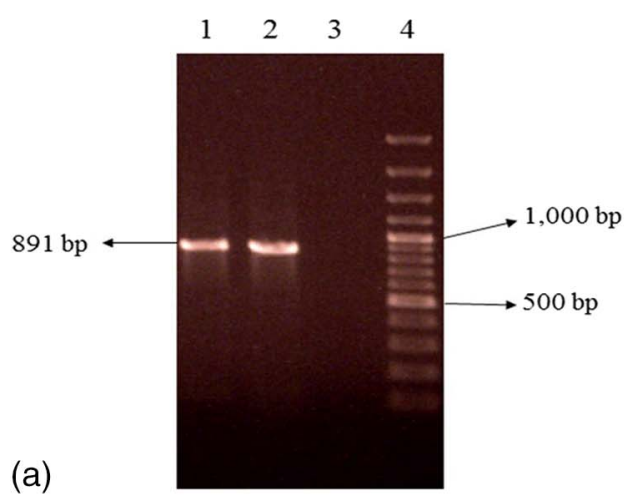

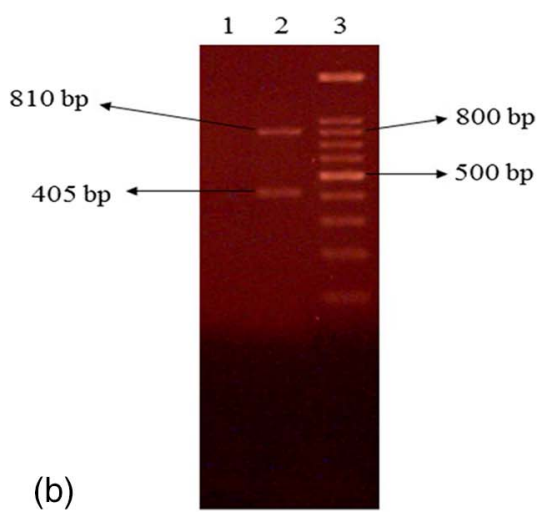

(b)

Figure 3. Representative $2 \%$ agarose gel electrophoresis of coa gene PCR products where 3 (b) and 4 (a) are DNA molecular size markers (100 bp ladder). (a) Isolates 1 and 2 showing single band, (b) isolate 2 showing two bands 


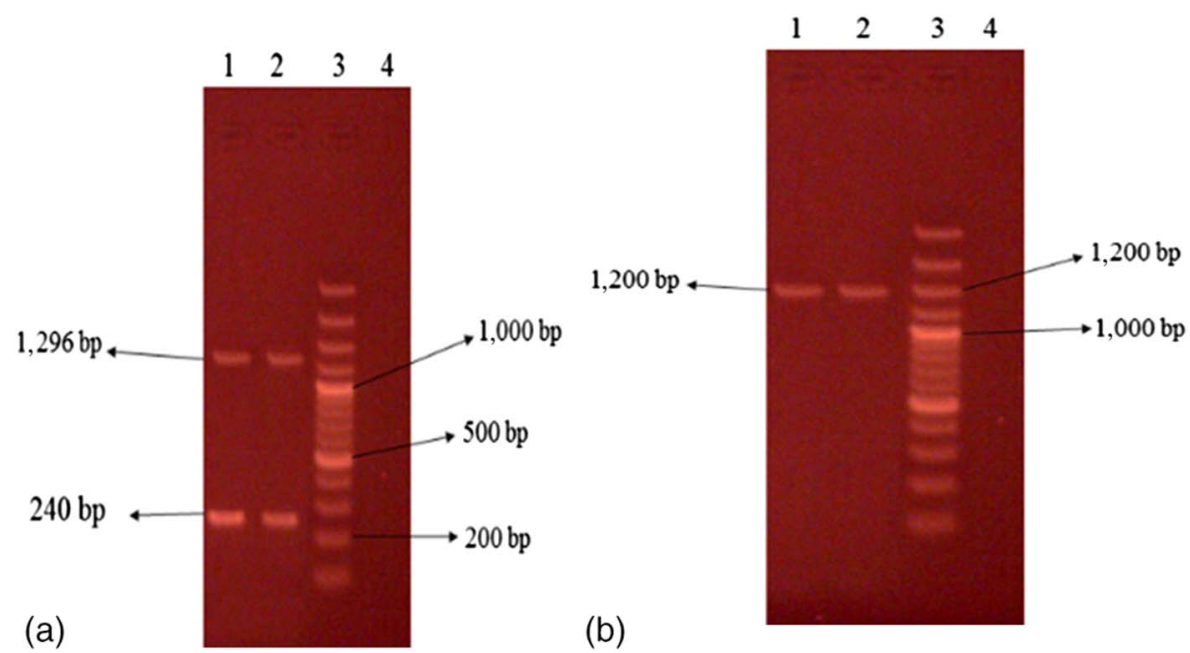

Figure 4. Representative $2 \%$ agarose gel electrophoresis of spa gene PCR products where lane 3 is DNA molecular size marker (100 bp ladder). (a) Isolates 1 and 2 showing two bands, (b) isolates 1 and 2 showing single band

genes in database GenBank, enzymes HaeIII and Bsp1431 were used that has proper restriction sites on coa and spa genes (Figures 5 and 6).

\section{Discussion}

Distribution of resistance against different antibiotics among strains of S. aureus has created many problems in different parts of the world. Unfortunately, there is little information on the resistance rate of $S$. aureus strains against different antibiotics in some cities of Iran. In this study, $68 \%$ of $S$. aureus strains were isolated from patients who are resistant to cefoxitin (MRSA) and this rate is more than that of studies conducted by some researchers. These results showed that the frequency of MRSA strains in the subjects is more related to infectology and surgical departments. Potential danger of the distribution of MRSA strains in a special care section has been paid attention due to the occurrence of more problems in the hospitals, various medical manipulation, and extensive consumption of antibiotics. Study of Zamani et al. [18], on 70 samples of S. aureus, showed that $50 \%$ were MRSA and considering antibiotic-resistance pattern, they showed resistance to tetracycline $(74.2 \%)$, co-trimoxazole $(68.5 \%)$, erythromycin $(68.5 \%)$, and ceftazidime (51.4\%). Studies by Moradi et al. [19], on 104 samples of $S$. aureus, showed that the highest rate of sensitivity was toward vancomycin (96.2\%), chloramphenicol $(88.2 \%)$, rifampin $(81.7 \%)$, and the lowest rate of resistance was toward cefoxitin (40.4\%). In a study by Lepsanovic et al. [20], 


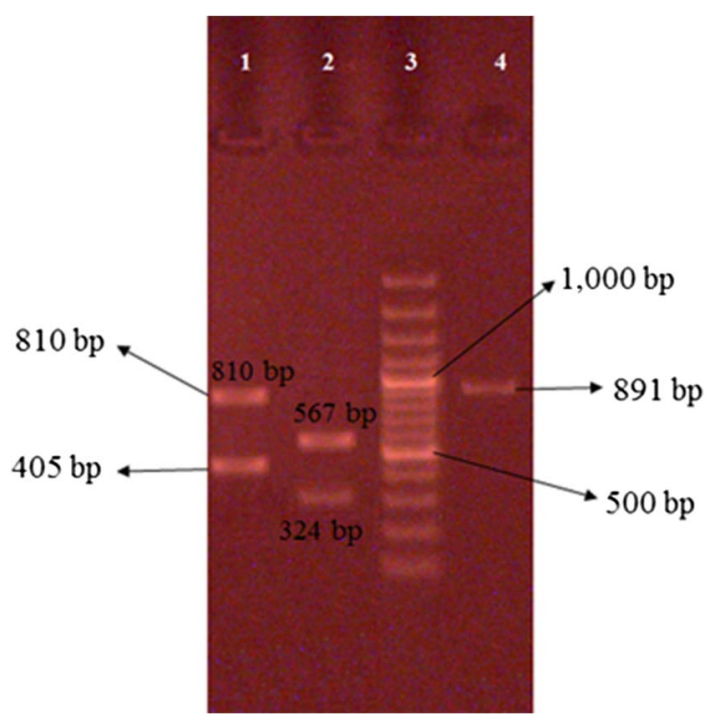

Figure 5. Restriction analysis of coa gene with HaeIII restriction enzyme. Column 3 is DNA molecular size marker (100 bp ladder), isolates $1-4$ showing 1 band of coa gene that remained uncut, and isolate 2 showing two bands of coa gene PCR product

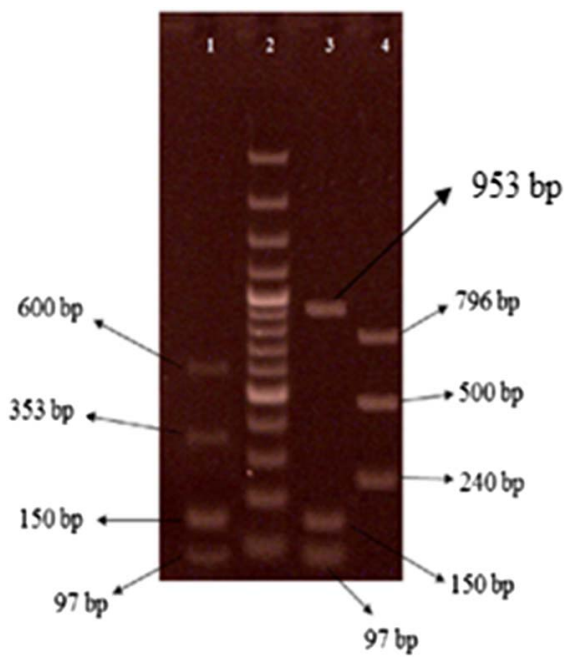

Figure 6. Restriction analysis of spa gene with $B s p 1431$ restriction enzyme. Column 2 is DNA molecular size marker (100 bp ladder). Isolate 1 showing four bands of spa gene, isolate 3 showing three bands of spa gene, and isolate 4 showing three bands of spa gene PCR product

all MRSA strains from hospitalized patients were resistant to one or more non- $\beta$-lactam antibiotics while $52 \%$ were multiresistant. In isolates from healthy people, $16 \%$ were sensitive to all non- $\beta$-lactam antibiotics and $40 \%$ were 
multiresistant. Study by Haghgoo et al. [21], on 13 samples of $S$. aureus, isolated from the cultivation of blood of patients kept in Shahid Madani Hospital in Tabriz, Iran, showed that the highest resistance was toward methicillin and ceftriaxone (31\%). In a study by Karasartova et al. [22], 43 phages isolated from 48 MRSA were investigated for carrying toxin genes including the sak, eta, lukf-pv, sea, selp, sek, seg, seq chp, and scn virulence genes using PCR and Southern blot. The results indicate that prophages encode a significant proportion of MRSA virulence factors. Distribution of strains of cefoxitin-resistant $S$. aureus in this study is more than that in the mentioned studies. $p v l$ is a virulence factor that is carried by a bacteriophage and it can be transferred to other Staphylococcus strains. Positive strains of $p v l$ have high virulence and are responsible for severe infections like infection of bone joint and necrosis pneumonia. Therefore, rapid distinguishing and on time control of the $p v l$-positive strains is necessary. This is the first study to determine the frequency of $p v l$ gene in clinical samples from Rasht, Iran. In this study, it was shown that from 50 isolates of $S$. aureus, 20\% (10 samples) carried this gene and were more frequent in samples of urine and also it was shown that no significant relationship existed between $p v l$ and mecA genes among the strains. Molla-abbaszadeh et al. [23], considered the distribution of $p v l$ gene in strains of S. aureus and from 100 strains, 18 (18\%) were reported to be positive, regarding the existence of $p v l$ gene and from these subjects, 94.4\% MRSA and 56.6\% were methicillin-sensitive Staphylococcus aureus (MSSA). Khosravi et al. [17] reported distribution of $p v l$ gene in MRSA strains was $7.2 \%$ and in MSSA strains, it was $33.3 \%$ [17]. Recently, more studies have been conducted on positive $p v l$ strains of MRSA, whereas positive $p v l$ infections of MSSA play important role in the distribution of positive $p v l$ strains. About $60 \%$ of the total positive strains for $p v l$ in England in the past 5 years were sensitive to methicillin [24]. A study of Cupane et al. [25] showed that that $75 \%$ of strains of $S$. aureus had $p v l$ gene and most of them (60.7\%) were MRSA. In a study by Osman et al. [26], among 210 S. aureus samples, $p v l$ gene was observed in $58 \%$. Brown et al. [8] considered 1,055 $S$. aureus regarding existence of $p v l$ gene, 377 strains $(35.7 \%)$ had this gene, which is most resistant to methicillin. In a study of Lima et al. [27], on strains of MRSA isolated from patients with cystic fibrosis showed that almost half of the strains carried $p v l$ gene. In this study, distribution of $p v l$ gene in MRSA strains was more that $60 \%$ of the samples of positive $p v l$ (six samples) in strains MRSA and $40 \%$ (4 samples) in MSSA strains. The distribution of $p v l$ gene in the study of Molla-abbaszadeh et al. [23] and Khosravi et al. [17] was more than that of the study of Cupane et al. [25] and Osman et al. [26], and in the study of Lima et al. [27], it was less, and it seems that the distribution of positive $p v l$ gene was more in MRSA strains in all the mentioned studies. Coa gene exists in all Staphylococcus strains and shows capability of typing for this gene; therefore, 
it is a main gene for distinguishing $S$. aureus. In this study, three types of coa genes were observed among the strains that there was band of $405 \mathrm{bp}$ in most strains. Existence of more than one band shows more than one allele in coa gene, which shows that the strain produces different variants of this protein. Polymorphism existing in coa gene resulted from deletion and insertion at the end of $3^{\prime}$ of coa gene and gene sizes changes in this way. Himabindu et al. [28] showed that PCR product of coa gene has three band patterns and most isolates had $812 \mathrm{bp}$, whereas in this study, band of $405 \mathrm{bp}$ existed in most strains. According to studies of Lawrence et al. [29], typing of coa gene creates common band of $402 \mathrm{bp}$, which is similar to the present studies in which 405 bp band occurred in most strains. In this study, the PCR product of some strains was not cut by HaeIII enzyme and it showed that they do not have cutting site for HaeIII. Study of Lawrence et al. [29] demonstrated that band of 402 bp by HaeIII enzyme was changed to bands 176 , 146 , and $81 \mathrm{bp}$. In case that in our studies, band of 405 bp have not been cut by HaeIII enzyme. In a study by Karahan et al. [30], in Turkey, it was shown that from 200 strains of S. aureus, $161(80.5 \%)$ had polymorphism in coa gene. About $83.9 \%$ of these strains had a band with size of $500-1,400$ bp and $16.1 \%$ had two pieces. Size of spa gene based on its $\mathrm{X}$ region is polymorphic and has repetitive sequence of $24 \mathrm{bp}$; this number and sequence in different strains are different. Size of spa gene in this study was created in the $3^{\prime}$ end with different sizes, which were observed to be $1,200,1,296$, and 240 bp in gels. Inexistence of spa gene was observed in three strains. Study by Shakeri et al. [10] showed that spa gene was not present in 5\% of the strains. Schmitz et al. [31] showed that five types of spa gene were reported among strains of $S$. aureus. They reported that the number of repetitive sequences of $\mathrm{X}$ region of spa gene is related to the epidemiological compatibility. Strains having shorter length cannot attach to the epithelium of nose; therefore, exit through breath, caught, and sneezed out through the nose. It should be noted that this is the first study conducted on molecular typing of clinical isolates of S. aureus based on coa and spa genes samples, from hospitals of Rasht, Iran; this shows difference of genetic patterns. In some cases, some similarities are observed in different sections, which probably show a kind of bacterial transfer between the staff and hospitals.

\section{Conclusions}

The results of this study showed increasing resistance of clinical samples of $S$. aureus to different antibiotics. The resistance rate of $S$. aureus to cefoxitin was high and on the other hand, its resistance toward other antibiotics, such as $\beta$-lactam, aminoglycosides, macrolides, and quinolone, is high. The $p v l$ gene shows 
relatively high frequency in this region as compared with other places in the world. Since infection with the bacteria, $S$. aureus is very prevalent and toxin-producing bacteria create problems at the society level, so it is necessary to use proper diagnostic method, especially molecular methods to identify virulence factors.

\section{Conflict of Interest}

No conflict of interest associated with this work.

\section{References}

1. Masalha, M., Borovok, I., Schreiber, R., Aharonowitz, Y., Cohen, G.: Analysis of transcription of the Staphylococcus aureus aerobic class Ib and anaerobic class III ribonucleotide reductase genes in response to oxygen. J Bacteriol 183, 7260-7272 (2001).

2. Tarai, B., Das, P., Kumar, D.: Recurrent challenges for clinicians: Emergence of methicillinresistant, vancomycin resistance, and current treatment options. J Lab Physicians 5, 71-78 (2013).

3. Shorr, A. F.: Epidemiology of Staphylococcal resistance. Clin Infect Dis 45, 171-176 (2007).

4. Lina, G., Piemont, Y., Godail-Gamot, F., Bes, M., Peter, M. O., Gauduchon, V.: Involvement of Panton-Valentine leukocidin-producing Staphylococcus aureus in primary skin infections and pneumonia. Clin Infect Dis 29, 1128-1132 (1999).

5. Supersac, G., Prevost, G., Piemont, Y.: Sequencing of leucocidin R from Staphylococcus aureus P83 suggests that Staphylococcal leucocidins and gamma-hemolysin are members of a single, two-component family of toxins. Infect Immun 61, 580-587 (1993).

6. Clark, J.: A brief review of Panton-Valentine leukocidin producing staphylococcal infections in the intensive therapy unit. Curr Anaesth Crit Care 19, 330-332 (2008).

7. Colin, D. A., Mazurier, I., Sire, S., Finck-Barbancon, V.: Interaction of the two components of leukocidin from Staphylococcus aureus with human polymorphonuclear leukocyte membranes: Sequential binding and subsequent activation. Infect Immun 62, 31843190 (1994).

8. Brown, M. L., O’Hara, F. P., Close, N. M., Mera, R. M., Miller, L. A., Suaya, J. A.: Prevalence and sequence variation of Panton-Valentine leukocidin in methicillin-resistant and methicillin-susceptible Staphylococcus aureus strains in the United States. J Clin Microbiol 50, 86-90 (2012).

9. Simpson, K. H., Bowden, G., Hook, M., Anvari, B.: Measurement of adhesive forces between individual Staphylococcus aureus MSCRAMMs and protein-coated surfaces by use of optical tweezers. J Bacteriol 185, 2031-2035 (2003).

10. Shakeri, F., Shojai, A., Golalipour, M., Alang, S. R., Vaez, H., Ghaemi, E. A.: Spa diversity among MRSA and MSSA strains of Staphylococcus aureus in north of Iran. Int J Microbiol 2010, Article ID 351397 (2010).

11. Ravathi, G., Puri, J., Jain, B. K.: Bacteriology of burns. Burns 24, 347-349 (1998). 
12. Lu, S. Y., Chang, F. Y., Cheng, C. C., Lee, K. D., Huang, Y. C.: Methicillin-resistant Staphylococcus aureus nasal colonization among adult patients visiting emergency department in a Medical Center in Taiwan. PLoS One 6, e18620 (2011).

13. Clinical and Laboratory Standards Institute: Performance Standards for Antimicrobial Susceptibility Testing, Vol. 17. Clinical and Laboratory Standards Institute, Wayne, PA, 2007.

14. Ghaznavi-Rad, E., Nor Shamsudin, M., Sekawi, Z., Belkum, A., Neela, V.: A simplified multiplex PCR assay for fast and easy discrimination of globally distributed staphylococcal cassette chromosome mec types in meticillin-resistant Staphylococcus aureus. Med Microbiol 59, 1135-1139 (2010).

15. Moghadam, S., Havaei, A.: Prevalence of methicillin-resistant Staphylococcus aureus carrying Panton-Valentine leukocidin gene in cutaneous infections in the City of Isfahan. $\mathrm{J}$ Med Bacteriol 19, 9-16 (2012).

16. Mostafa, S.: Molecular typing of methicillin resistant Staphylococcus aureus by spa gene polymorphism. Afr J Microbiol Res 7, 755-759 (2013).

17. Khosravi, A. D., Hoveizavi, H., Farshadzadeh, Z.: The prevalence of genes encoding leukocidins in Staphylococcus aureus strains resistant and sensitive to methicillin isolated from burn patients in Taleghani Hospital, Ahvaz, Iran. Burns 38, 247-251 (2012).

18. Zamani, A., Sadeghian, S., Ghaderkhani, J., Alikhani, M. Y., Najafimosleh, M., Taghi Goodarzi, M.: Detection of methicillin-resistance (mec-A) gene in Staphylococcus aureus strains by PCR and determination of antibiotic susceptibility. Ann Microbiol 57, 273-276 (2007).

19. Moradi, N., Javadpour, S., Karmostaji, A.: Reduced sensitivity of Staphylococcus aureus to vancomycin. Hormozgan Uni Med Sci 15, 169-177 (2011).

20. Lepsanovic, Z., Jeremic, L. P., Lazic, S., Cirkovic, I.: High prevalence and resistance patterns of community-associated methicillin-resistant Staphylococcus aureus in the Pomoravlje Region, Serbia. Acta Microbiol Immunol Hung 63, 83-92 (2016).

21. Haghgoo, S., Moaddab, S., Rafi, A.: Study of antibiotic resistance pattern of Staphylococcus aureus strains isolated from blood cultures in Tabriz Shahid Madani Hospital. J Jundishapur 3, 383-390 (2012).

22. Karasartova, D., Cavusoglu, Z. B., Turegun, B., Ozsan, M. T., Sahin, F.: Identification of virulence genes carried by bacteriophages obtained from clinically isolated methicillinresistant Staphylococcus aureus. Acta Microbiol Immunol Hung 63, 433-447 (2016).

23. Molla-abbaszadeh, H., Mobayen, H., Mirzaei, H.: Identification of Panton-Valentine leukocidin $(p v l)$ genes in Staphylococcus aureus isolated from in-patients of Emam Reza and Shohada Hospitals of Tabriz by real-time PCR. Iran J Med Microbiol 6, 72-80 (2013).

24. Otokunefor, K., Sloan, T., Kearns, A. M., James, R.: Molecular characterization and Panton-Valentine leukocidin typing of community-acquired methicillin-sensitive Staphylococcus aureus clinical isolates. J Clin Microbiol 50, 3069-3072 (2012).

25. Cupane, L., Pugacova, N., Berzina, D., Cauce, V., Gardovska, D., Miklasevics, E.: Patients with Panton-Valentine leukocidin positive Staphylococcus aureus infections run an increased risk of longer hospitalisation. Int J Mol Epidemiol Genet 3, 48-55 (2012).

26. Osman, N. A. M., Alrayah, I. E., Mohamed, Y. M., El-Eragi, A. M., Eldirdery, M. M., Salih, M. A.: Molecular study of Panton-Valentine leukocidin genes among Staphylococcus aureus clinical isolates in Khartoum State, Sudan. Am J Microbiol Res 3, 107-111 (2015). 
27. Lima, D. F., Brazao, N. B., Folescu, T. W., Neves, F. P., Ferreira, A. G., Santos, E. A., Marques, E. A., Leao, R. S.: Panton-Valentine leukocidin (PVL) gene carriage among Staphylococcus aureus strains with SCCmec types I, III, IV, and V recovered from cystic fibrosis pediatric patients in Brazil. Diagn Microbiol Infect Dis 78, 59-62 (2014).

28. Himabindu, M., Muthamilselvan, D. S., Bishi, D. K., Verma, R. S.: Molecular analysis of coagulase gene polymorphism in clinical isolates of methicilin resistant Staphylococcus aureus by restriction fragment length polymorphism based genotyping. Am J Infect Dis $\mathbf{5}$, 163-169 (2009).

29. Lawrence, C., Cosseron, M., Mimoz, O.: Use of coagulase gene typing method for detection of carrier of methicillin resistant Staphylococcus aureus. J Antimicrob Chemother 37, 687-696 (1996).

30. Karahan, M., Nuri, M., Cetinkaya, B.: Investigation of virulence genes by PCR in Stapylococcus aureus isolates originated from subclinical bovine mastitis in Turkey. Pak Vet J 31, 249-253 (2011).

31. Schmitz, F., Steiert, M., Tichy, H. V.: Typing of methicillin-resistant Staphylococcus aureus isolates from Dusseldorf by six genotypic methods. J Med Microbiol 47, 341-351 (1998). 